\title{
A Lightly Roasted Editor on His 65th Birthday
}

At the 1986 ASMS Conference in Cincinnati, there was a contest between the Younger Mass Spectrometrists (YMS) - although there are some who say that the group should be known as the Adolescent Mass Spectrometrists (AMS) - and the Middle-Aged Turks (MAT). (Proceedings of the 34th Annual Conference on Mass Spectrometry and Allied Topics, June 8-13, 1986, Cincinnati, OH, p.1157) Part of the competition involved submission of limericks such as the following:

There once was a maestro from Lincoln

Whose head overheated from thinkin

His skull is now bare

Cause he lost all his hair

And now he just watches lights blinkin.

Now that the MATs are undergoing decomposition to Terribly-Old-Folk (TOF), it is appropriate to take some time and reflect on the decomposition pathway followed by the Editor of this journal.

Michael's academic journey began with a B.S. degree from St. John's University in 1962 followed by doctoral studies at the University of Minnesota under the direction of Elgin Hill (1966) and a year of postdoctoral research (1966-67) in isotope effects in physical organic chemistry with E. Thornton at the University of Pennsylvania. These years provided Michael with a firm foundation in physical organic chemistry, combining an introduction to the impact of 'measurement' science on chemistry with a thorough understanding of organic chemistry. Part of Thornton's research group was interested in kinetic isotope effects in mass spectrometry. So, the natural next step in his training was to undergo a rearrangement to McLafferty's Lab at Purdue University to study mass spectrometry, including ion cyclotron resonance MS. Thus, began our editor's descent along his decomposition pathway (1967-68).

Michael acquired more than just an interest in flat lands and mass spectrometry while at Purdue. He must have heard fond stories of Fred's childhood in Nebraska and of how great the Chemistry Department was there, because Dr. Michael Gross in 1968 became Assistant Professor Gross in the Department of Chemistry at

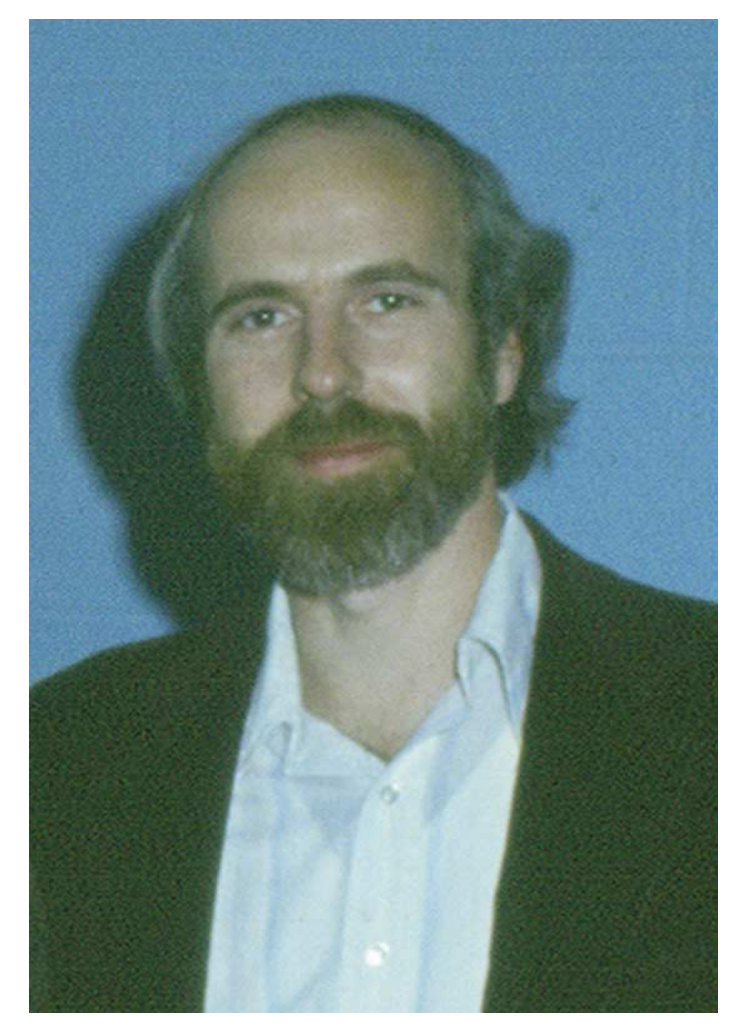

the University of Nebraska in Lincoln. One might say that this transition was a portent of some of his future endeavors, given that Nebraska was considered to be a remote site in the middle of nowhere. At this stage, the young maestro still had a relatively full head of hair. Michael's background in physical organic chemistry and training in Fred McLafferty's Lab asserted itself and separated Michael's research perspective from many of his contemporaries in mass spectrometry with physical chemistry backgrounds.

To the state where tall corn grows, And people wear red polyester clothes,

With aspirations to obtain

Scientific publication fame,

There MLG made ions decompose. 
Late at night one can get the present Professor Gross to relate the uncertainty and worries he felt at trying to measure up to the Young Turks in academics at that time, the ion chemists, analytical instrumentalists, and even the others also focused on physical organic applications. However, his early papers on cycloaddition and cycloreversion reactions and the application of ion cyclotron resonance MS to ion-molecule reactions and to ion structure determinations lead him to become Fully-Tenured. On the basis of these early publications, his reputation grew and eventually Michael underwent another transition to a more stable state, the MCMS years.

In 1978, Michael along with Charlie Wilkins and Gerry Meisels was successful in obtaining NSF funding for one of six original NSF instrumentation facilities, the Midwest Center for Mass Spectrometry (MCMS) whose motto became 'State-of-the-Art Mass Spectrometry in the Middle of Nowhere.' The Center started its life with a high resolution Kratos MS-50, an FTMS and a rebuilt Hitachi reverse geometry instrument and added a Kratos MS-80 and the centerpiece of MCMS, a Kratos MS-50 three-sector tandem mass spectrometer which was quickly adapted for the then newly emergent ionization technique for biological molecules, fast atom bombardment (FAB). With the establishment of the center, Michael was now a Middle-Aged-Loosely-Defined Investigator (Badly-Aging-Loosely-Defined Investigator?) and his research interests coalesced into several major themes: the characterization of structurally important ions desorbed from biomolecules; studies of adduct formation in ion-molecule reactions that can be collisionally stabilized in a high pressure ion source; pursuit of collaborations and service in biological problem solving and ion chemistry through MCMS; the use of $\mathrm{FAB} / \mathrm{MS}$ for structural studies of polar organic and organometallic molecules; and trace analyses of polychlorodibenzodioxins and dibenzofurans. Michael's major scientific contributions from this time period included the study of distonic ions, the application of $\mathrm{FAB} / \mathrm{MS} / \mathrm{MS}$ to cyclic peptides, high mass peptides, nucleosides and modified nucleotides and oligonucleotides, and the newly-discovered-and very appropriately named for something discovered in the middleof-nowhere-remote-site fragmentation.

With fatty acids, three sectors and FAB, 'Charge-remote-fragmentation' hit the lab, His success came fast,

His science became first class.

JASMS editorship he did nab.

With renewal of the Center grant in 1987, Michael, along with engineers from VG Analytical, designed the high resolution magnetic sector tandem mass spectrometer, VG ZAB-T, which incorporated a multichannel detector to drastically improve the duty cycle for MS/MS data acquisition. This instrument was also designed especially to permit high energy fragmenta- tions to obtain structural information that could not be had in lower energy collision instruments. Given the timing of the design and manufacture of this instrument, it also serves as a bookend of the heavy metal era in MS. Another notable instrument proposed in the Center renewal proposal, but not built, was a magnetic sector/Time-of-Flight instrument that foreshadowed hybrid instruments such as the Q-TOFs.

In addition to his scientific endeavors at UNL, but like his interest in distonic ions, Professor Gross's academic career also had a distonic character. Thoroughly connected to his science but often generally viewed as separate was Michael Gross, the Mentor Scientist. Michael's dedication to his students was recognized by UNL when it awarded him the Amoco Distinguished Teaching Medal in 1978. The University of Nebraska also recognized his overall efforts and achievements by awarding him two named Chairs in Chemistry, 3M Alumni Professor of Chemistry (198388) and C. Petrus Peterson Professor of Chemistry (1988-1994).

During UNL/MCMS days he served on many editorial boards and as editor of Mass Spectrometry Reviews. In the late 1980s, the American Society for Mass Spectrometry recognized the need for a high-quality Society journal that would help to unify the field and announced the inauguration of the Journal of the American Society for Mass Spectrometry in 1990 and that Michael Gross would be the editor.

In 1994, a high energy collision occurred, redirecting Michael's fragmentation onto a new pathway eventually via a rearrangement reaction which in some ways resembled a simple cleavage. NSF funding for the instrumentation centers dried up and redirected Michael's major source of research funding to the NIH. As most of us are aware, NIH funding for mass spectrometry is much easier to obtain when there are strong biological components and collaborations in the proposal. So, when Washington University in St. Louis approached Michael to accept a position as the principal investigator (PI) for their NIH-funded Washington University Research Resource in Mass Spectrometry and a joint appointment in the Medical School, Michael cleaved his ties to Nebraska and rearranged his life and lab to St. Louis. True to his roots though, he elected to set up shop in the Chemistry Department of the 'Hilltop Campus' rather than the Medical School because of his desire to continue to mentor graduate students and post-docs.

As the Midwest Center for Mass Spec grew, Plenty of students would pass through,

But when finances began to pinch.

He said the answer is a cinch, Goodbye Lincoln. Hello, St. Lou.

At Washington University, his science continued on its high-energy course, and expanded further into biological applications where he used his previous experi- 
ence to adapt $\mathrm{H} / \mathrm{D}$ exchange procedures to develop a new method for obtaining binding constants in protein/ligand equilibria. In 1999 Michael's research efforts and contributions to the field of mass spectrometry were recognized by the American Chemical Society's awarding him the Frank H. Field and Joe L. Franklin Award for Outstanding Achievement in Mass Spectrometry for his contributions in basic ion chemistry (distonic ions, electrocyclic, cycloaddition, charge-remote fragmentation), instrumentation (MS/MS, FTICR), trace analysis (ppt TCDD), and leadership (editor of two journals, director of two national MS facilities). Michael was selected by the members of the Governing Committee of the International Mass Spectrometry Society to receive one of the three Thomson Medals to be awarded at the IMSC in Prague in 2006.

His continued collision course with great mass spectrometry didn't lead, however, to a total coulombic ego explosion. While many senior faculty would look with disdain upon teaching undergraduate chemistry sections, Professor Gross finds the challenge both refreshing and rewarding. His ability to describe complex chemical concepts to students is legendary on campus and has been repeatedly recognized by awards from both the undergraduate and graduate student bodies for his dedication to the art and science of teaching chemistry and mentoring graduate students-Outstanding Faculty Mentor Award, 2001 and Special Recognition for Excellence in Mentoring, 2002-2005, Washington University Graduate Student Senate.

Since moving to Washington University, Michael has continued as editor of JASMS, and the prestige of the journal has grown significantly under his careful guidance. Not only have the number of papers submitted grown, but the citation index for the journal has also increased dramatically, and JASMS currently has one of the highest impact factors in analytical chemistry.

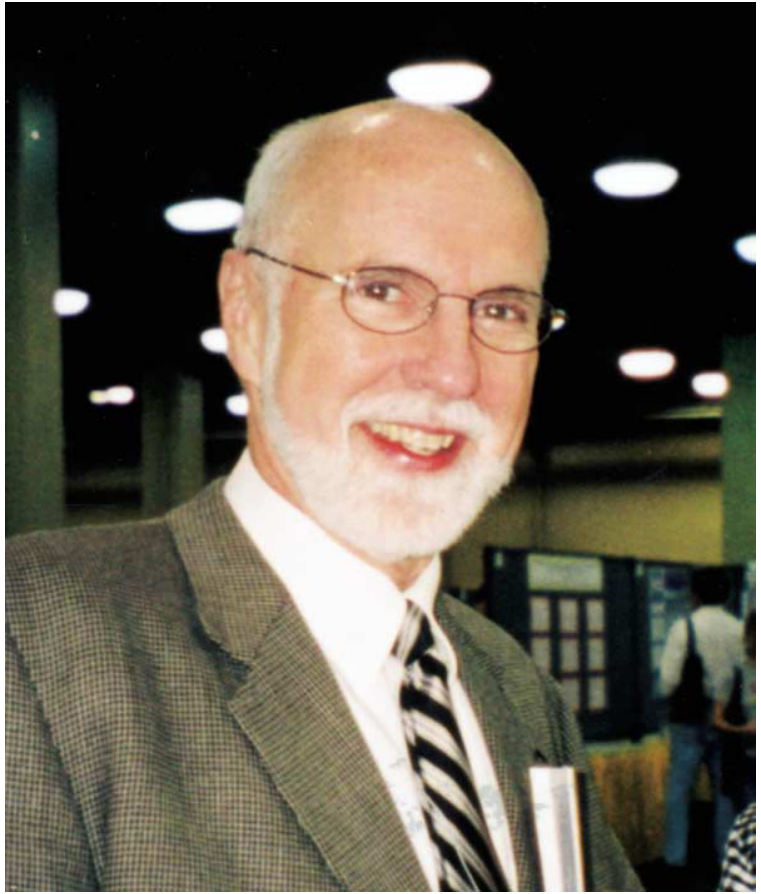

So now that he is an Especially Senior Investigator, we hope that all of you will wish Michael a happy 65th birthday and that his fragmentation pathway has numerous steps yet to tread.

Like an old dog and his shoe, $\mathrm{He}^{\prime}$ s right at home at Washington U. Although he's turning sixty-five,

His science is still very alive,

Support from social security, he'll pursue.

By Anonymous 